\title{
主として粘度および分子量の変化による歯科用印象材 としてのポリサルフアイドゴムの硬化機構の研究
}

（第 7 報） $\mathrm{KMnO}_{4}$ 党縮合酸化剂己する新らしいポリサルフアイド 系の歯科用印象材について

安田周治 東京医科齿科大学歯学部第二理工学教室（指導 : 神沢教授・東助教授)

(昭和 36 年 7 月 10 日受付)

\section{Discussions on the Setting Mechanism of Polysulfide Rubber as the Dental Impression Materials, Chiefly Viewing from the Variations of Viscosity and Molecular Weight}

(Part 7) Polysulfide Impression Material by Potassium Permanganate

by

\section{Shuji Yasuda}

The second Department of Dental Technology, Tokyo Medical and Dental University (Director: Prof. Yasuo Kanzawa, Assist Prof. Setuo Higashi)

\section{まえがき}

第 6 報 ${ }^{26)}$ で著者は $\mathrm{KMnO}_{4}$ を縮合用酸化剂 と した場合のポリサルファイドの縮合能力を，粘度 と分子量の変化を測定して検討し，その結果から 試験用の印象材を作成して，その硬化特性および 生成物の諸性質を調査し, 実用価值のあるこの系 の歯科用印象材をうる基本観念を確立したので, 本報ではその結果に基づいて修正した試作品を調 製して，その諸性質の試験を行ない，あわせて臨 床実験による検討を行なつた。

I 新らしい印象材の硬化曲線の作成, および 可塑度について

第 6 報 ${ }^{26)}$ において著者が新らしく提案した $\mathrm{KMnO}_{4}$ を縮合酸化剂とする,ポリサルファイド 系の 14 種類の組成の試作印象材を調製し，その 硬化の特性および生成物の諸性質を検討して, そ
の結果を基礎にし実用に適する印象材を試作して 硬化曲線を作成し，可塑度および残留ひずみなど も測定して見た。

\section{実験の方法}

第 6 報 ${ }^{26)}$ と同様の方法で温度一時間曲線と, シ ョア弾性試験機およびかたさ試験機を用いて弾性 一時間曲線およびかたさ一時間曲線を作成し，一 方プセジョン可塑度計を用いて, 硬化後の試料に $3.5 \mathrm{~mm}$ 径の半鋼球の押込体を, 最初試料の面か ら $3 \mathrm{~mm}$ 沈めて, $1 \mathrm{~kg}$ の荷重を 60 秒間かけた 時の沈み $\mathrm{H}_{1}$ (プセジョンかたさ) と, 荷重を取 り去つた時に残留した 沈み $\mathrm{H}_{2}$ (残留ひずみ) を 測定し, $\mathrm{P}=\frac{\mathrm{H}_{0}-\mathrm{H}_{2}}{\mathrm{H}_{0}-\mathrm{H}_{1}}$ 式 $^{11}$ とつて, 硬化後の 可塑度 $\mathrm{P}$ を計算で求めた。 


\section{実験の結果}

この実験に用いた印象材の組成は，A剂は分子 量約 4000 の液状のポリサルファイド $72 \%, \mathrm{SiO}_{2}$ $28 \%$ から成り，B剤は $\mathrm{KMnO}_{4} 4 \%, \mathrm{SiO}_{2} 30 \%$ $\mathrm{TiO}_{2} 30 \%$ ， D.B.P $36 \%$ あっつて，この印象材 につき練和後の内部温度, かたさ, 弾性の変化を 測定し，その結果を図 156 に示した。

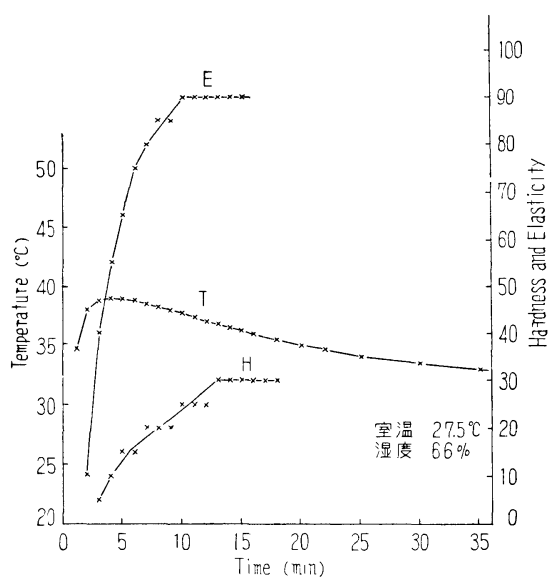

図 156 No. $16 \mathrm{~A}_{1}-\mathrm{B}_{13}$ 硬化曲線

この印象材の硬化後のプセジョンかたさは 290 残留ひずみは 71 , 試料の厚さは 1250 であり,こ れから計算して求めた可塑度は 1.228 である。

この結果を市販印象材と比べると, 市販のゴム 質印象材の可塑度は 1.1 付近であるからはるかに 優秀といえるし，プセジョンかたさはアルジネー 卜印象材とほぼ同様で好適と考えられる, 他方残

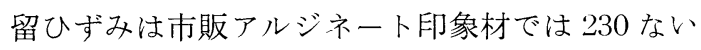
し 240 にも達するのに対してわずかに 71 である から，性能の点ではきわめて優秀といえる。しか もこの印象材は着色が少なくほとんど白色であ り, 美麗で清潔な感触を与え, 臨床用として好適 である。

II 寸法変化について

歯科界において各種補綴物や充てん物を作る場 合，その適合性の良否は印象に負う所が大であ り，モデル(または金型)上の寸法が印象上でどの 程度の正確さであらわされるかという忠実性のよ
いことはもつとも重要であり，また空気中および 液体中で寸法の変化の少ないこともまた操作上望 ましい条件である。

1 空気中および液体中での寸法変化

上ぶた，下ぶたおよび中胴の三部から成る金型 （砲金製，クロムメッキ）によつて， $1 \mathrm{~cm} \times 1 \mathrm{~cm}$ $\times 10 \mathrm{~cm}$ の印象を作製するようにし，上ぶたは左 右 2 コのオーバーフローを設けて過剩の印象材が 流れ出るようにし,下ぶたの内面には約 $90 \mathrm{~mm} の$ 標点距離を表示する約 $10 \mu$ の太さの十字標識を 彫刻しておき，この標識を印象上に再現させてそ の寸法 $\mathrm{lx}$ を読取顕微鏡で測定し，金型上の標点 距離 $\mathrm{l}_{0}$ にたいして次式 ${ }^{1}$ によつて寸法変化を 100 分比によつて求めた。

$$
\begin{aligned}
& \mathrm{X}=\frac{\mathrm{l}_{0}-\frac{\mathrm{l}}{\mathrm{x}}}{\mathrm{l}_{0}} \times 100\left(\mathrm{l}_{0}>\mathrm{l} \mathrm{x} \text { のとき }\right) \\
& \mathrm{X}=\frac{\mathrm{l}_{\mathrm{x}}-\mathrm{l}_{\mathrm{n}}}{\mathrm{l}_{0}} \times 100\left(\mathrm{l} \mathrm{x}<\mathrm{l}_{0} \text { のとき }\right)
\end{aligned}
$$

上の式の場合は収縮，下の式の場合は膨張であ る。なお測定は印象採取值後に行なつた。

\section{実験の結果}

i 標準偏差 図 157 は金型上の標点距離の測

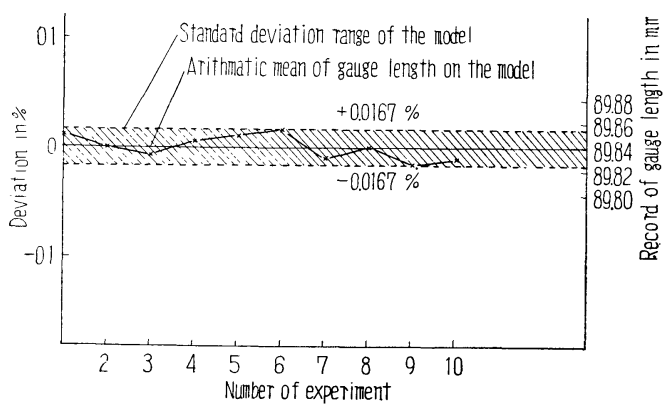

図 157 標準偏差の測定

定を繰り返した時の標準偏差を示していて，この 方法によつてえた結果の信頼度を確かめたもので 西る。

ii 空気中に㧍ける寸法変化 図158 は新しい 印象材について行なつた空気中の寸法変化を示 し，図中の斜線の部分は標準偏差域である。この 実験の経果から空気中では寸法変化のないことが わかつた。 


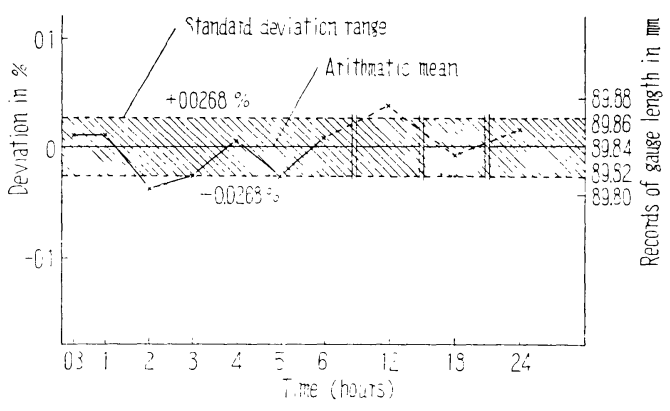

図 158 空気中における寸法変化

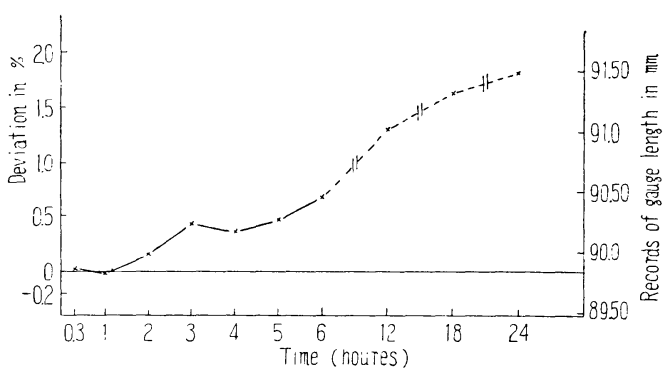

図 159 水中における寸法変化

iii 水中に抢ける寸法変化 図 159 は水に浸漬 した場合の寸法変化を示す。この実験の結果から 水中における短時間の浸漬では, 寸法変化がほと んどないことがわかつた。

iv エチルアルコール中の寸法変化 図160 は

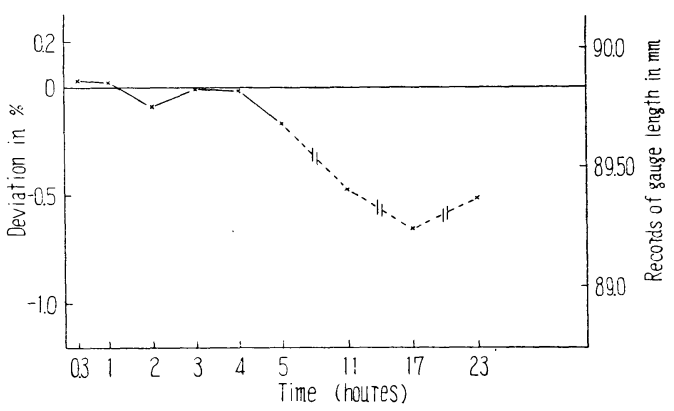

図 160 エチルアルコール中の寸法変化

エチルアルコール中に浸漬した場合の寸法変化を 示す。市販印象材は浸漬すると間もなくわずかな がら収縮するが，この新しい印象材は短時間の浸 漬では，ほとんど寸法変化のないことがわかつ た。

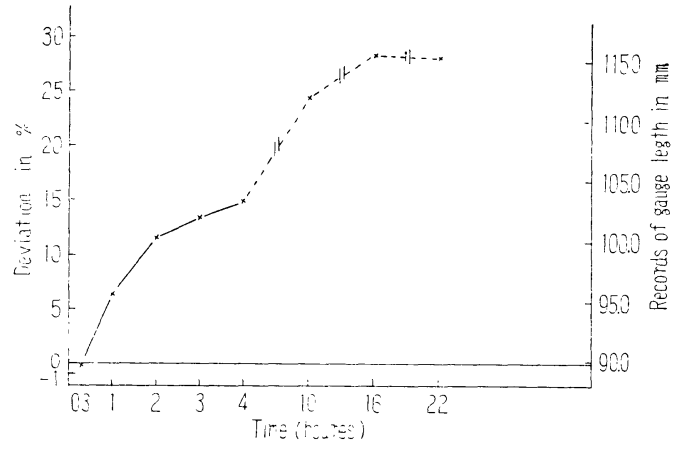

図 161 ベンゾール中におけう寸法変化

v ベンゼン中における寸法変化図 161 は心゙ ンゼン中における寸法変化を示す。

この実験の結果からベンゼン中では市販印象材 とおなじように，約 $30 \%$ の膨張を示した後，崩 壊することがわかつた。

2. 忠実性

\section{実験の方法}

寸法変化の測定に使用したのと同じ金型を用い て, 金型上の標点距離 $l_{0}$ とモデル上の標点距離 1

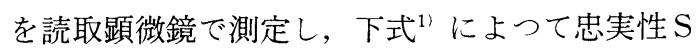
を 100 分比で算出した。

$$
\mathrm{S}=\frac{1_{0}-\left(\mathrm{l}_{0}-1\right)}{l_{0}} \times 100
$$

なを測定は印象採取後ただちに行なつた。

\section{実験の結果}

図 162 はこの実験の結果であるが，これによる

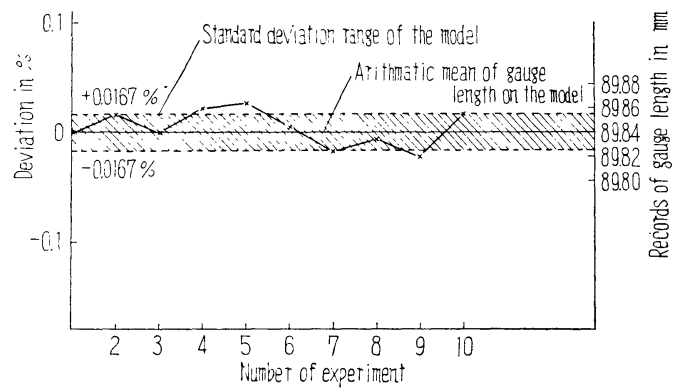

図 162 印象の忠実性

と偏差は $0.005 \%$ から $0.027 \%$ の間にあるから， 忠実性は $99.995 \%$ \% $99.973 \%$ 間にあることが 
わかる。

3 硬化時間一変化 $(\%)$ 曲線

新らしい印象材を 1 分間練和し（室温 $24^{\circ} \mathrm{C}$, 湿度 $60 \%$ ), 図 163 に示す狭窄部と最大膨隆部の

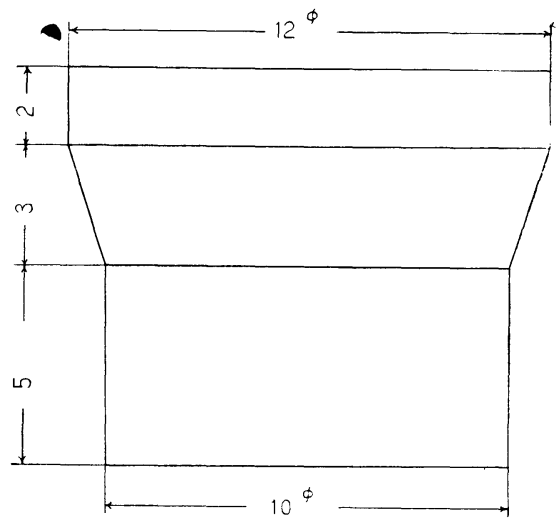

図 163 狭窄部と最大膨隆部の比が 10:12の金属の型 単位 $\mathrm{mm}$

比が $10: 12$ の金属の型に送入後 $36^{\circ} \mathrm{C}$ 飽和水蒸 気中で硬化させ，練和開始後 3 分から11分まで, 1 分毎に狭窄部と最大膨隆部の寸法変化 $(\%)$ の測定 を行なつた。

\section{実験の結果}

実験の結果を図 164 に示す。この実験の結果か

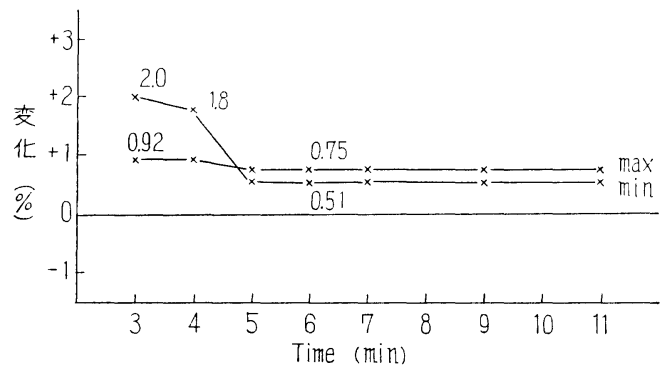

図 164 硬化時間一変化 $(\%)$ 曲線

ら，この印象材は 5 分間で硬化を終了するため， 印象の変形もほぼ一定となり，最大膨隆部の変形 （\%) は約 $0.75 \%$ で、狭窄部の寸法変化（\%) は $0.51 \%$ となり，市販ゴム質印象材のこの方法に よる変形が $1 \%$ 以上であるのに比較すればはるか
に優れているだけでなく，練和開始後約 5 分間で 急速に硬化するから，市販品が 15 分を必要とす るのに比較すれば，所要時間は約 $1 / 3$ となり，患 者の口中に印象材を送入している時間はわずかに 2 分ないし 3 分で十分で，きわめて優秀であると いえる。

\section{臨床実験について}

以上の実験から $\mathrm{KMnO}_{4}$ を縮合酸化剤に用い た新らしい印象材の諸性質が非常に優れているこ とがわかつたので，これを実際に適用して，臨床 的見地からの批判を專門医に依頼した結果，次の ような特色があることがわかつた。

i 練和操作は比較的かんたんで操作性が良好 である。

ii ゴム質印象材に共通の欠点である，悪臭は ほとんどなく，従来のものよりは好適である。

iii 色彩は白色に近いクリーム色で美麗であ り，清潔感があるだけでなく，細かい点の観察に 好都合である。

iv 印象面は非常に滑らかで，緻密である。

v 練和開始から印象撤去までわずか 5 分間で よく市販品の約 $1 / 3$ の時間で十分であり，能率よ く，患者に退くつ感㧍よび不快感を与えない。

vi 為害作用およびアレルギーを生じない。

vii 歯牙を污染せず，粘着性が少なくて，印象 撤去に骨がお机ない。

\section{考察および総括}

著者は主として粘度および分子量の変化から， ポリサルファイドの硬化機構を明らかにすること を企図し，最近多くの研究発表を行なつて斯界に 貢献した東 ${ }^{11}$ の業績を基礎として，本研究をはじ めたのであるが，その研究途上で幸にも $\mathrm{KMnO}_{4}$ が非常に優れたポリサルファイドの縮合能力を示 すことを発見することができた。第 6 報 ${ }^{26)}$ では $\mathrm{KMnO}_{4}$ を使用した場合の試作品について，その 硬化の特性および生成物の諸性質を検討して，実 用になしらる歯科用印象材の組成に関する基本観 念を確立したので，本報ではその結果に基ゔいて 
修正した試作品について，その特性および実用価 值を検討して，次に述べるような結果をえた。

$\mathrm{i}$ 従来のもののように有害な $\mathrm{PbO}_{2}$ をまつた く混合しないため，街生的見地から心配がない。

ii プセジョン可塑度は 1.228 で非常に優れて いる。

iii 空気中での寸法変化はない。

iv 水中での寸法変化は短時間の浸漬ではない から，唾液に接するための寸法変化はないものと 考えられる。

$\mathrm{v}$ 短時間の浸漬ではエチルアルコール中での 寸法変化がなく, アルコールによる消毒も可能 で，市販品には見られない特長である。

vi ベンゼン中での寸法変化は通常の市販品と ほぼ同様である。

vii 印象の忠実性は $99.984 \%$ で市販品より優 れている。

viii 狭窄部と最大膨隆部の 比が 10:12の金属 の型に送入して硬化時間一変化 $(\%)$ 曲線を作製し た結果, 印象材は 5 分間で硬化㧍よび寸法変化を 終り（練和開始後 5 分間で撤去可能）, しかも寸 法変化 $(\%)$ は $0.75 \%$ 以下で市販品よりはるかに 優秀である。

ix 臨床実験の結果から印象材として次の適応 性が認められた。練和は比較的かんたんで，臭は ほとんどなく，薄いクリーム色で，印象面は滑ら
かであり，為害作用およびアレルギー作用はな く，污染および粘着を起さず，特に練和開始後 5 分間で印象を撤去しても変形は非常にわずかであ る。

$\mathrm{x}$ 工業的利用について 著者が新らたに提案 した $\mathrm{KMnO}_{4}$ をポリサルファイドの縮合酸化剂 として用いる方法は，歯科用印象材の硬化の場合 には，約 $4 \%$ の使用で約 10 分間で硬化を完了さ せることができる能力から考えると，現在工業的 にはポリサルファイドの室温長時間加硫に, 縮合 酸化刘として $\mathrm{PbO}_{2}$ は約 $7.5 \%$ ，クメン八イド ロパーオキサイドは約 $6 \%$ を混合して，24 時間 加硫を行なつていることを考慮すれば， $\mathrm{KMnO}_{4}$ の加硫能力は抜群であり，はるかに少量の使用で 目的を達成できるものと推察され，この研究を基 磁として，その工業的応用が生れることは必至で ある。

\section{むすび}

本稿を閉じるに当つて御指導をたまわつた神沢康夫 教授ならびに東節男助教授に厚く謝意を表したい。

\section{参考文献}

26）安田周治, 口腔病学会雑誌, Vol 28, No 3 (1961).

1) S. Higashi,: The Bulletin of Tokoy Medical and Dental University Vol 6, Part I-XX (1959). 